\title{
Parfyymeistä ja rakkaudesta Mihail Kuzminin tuotannossa
}

Artikkelissa analysoidaan tuoksujen merkitystä eli ns. "olfaktorista koodia" Mihail Kuzminin poetiikassa ja kuvataan parfyymien erityistä roolia hänen omaleimaisen "kirjallisen maineensa" muotoutumisessa. Artikkelissa käsitellään kolmea tapausta, joissa tietyn hajuvesilaadun nimi esiintyy Kuzminin tuotannossa tai siihen liittyvissä teksteissä ja pyritään selittämään viittausten syitä kussakin yhteydessä. Tutkimuksesta ilmenee, että hajuvedet voivat toimia eräänlaisena "signaalina" ja ilmentää Kuzminin olemusta. Hajuvesibrändien nimet runoilija lisää teksteihinsä aikakauden merkkinä. Futuristien tapa käyttää "hajuvedentuoksua" halventavana epiteettinä antaa Kuzminille syyn ryhtyä epäsuoraan kirjalliseen polemiikkiin. Olfaktorinen tuoksujen ja parfyymien kuvasto liittyy Kuzminin tuotannossa oleellisesti rakkauden teeman käsittelyyn.

Aleksandra Pahomova

Mihail Kuzminia (1872-1936) pidetään yhtenä venäläisen modernismin keskeisimmistä nimistä. Hän niitti mainetta tuotteliaana runoilijana ja prosaistina, näytelmäkirjailijana, muusikkona ja kriitikkona. ${ }^{1}$ Laajaa tuotantoakin kuuluisampi lienee kuitenkin hänen hahmonsa, joka vakiinnutti paikkansa lukuisissa aikalaiskirjoituksissa ja muistelmissa. Kuzmin esitetään niissä venäläisen kulttuurin "hopeakauden" henkilöitymänä kiireestä kantapäähän. Elegantin runoilijan hahmossa heijastuu aikakauden äärimmäisyyksiin viety hienosyinen maailmankatsomus, jossa kirjallisuus ja elämä yhdistyivät. 
Yksi Kuzminin kirjallisen hahmon kulmakivistä oli tarkkaan harkittu estetismi, joka näyttäytyi niin hänen kirjoituksissaan kuin arjen kanssakäymisissä ja muuttui eräänlaiseksi legendaksi jo kirjailijan elinaikana. Muiden muassa runoilija Irina Odojevtseva kuvasi muistelmissaan Kuzminin ympärillä vallinnutta arvoituksellista ilmapiiriä: "En ole vielä kertaakaan nähnyt Kuzminia. Mutta olen kuullut hänestä monta varsin ristiriitaista tarinaa. Niiden pohjalta ei parhaalla tahdollakaan pysty luomaan kokonaiskuvaa Kuzminin hahmosta tai biografiasta: Kuzmin on esteetikkojen kuningas, muodin ja tyylin edelläkävijä. Hän on Venäjän Brummell ${ }^{2}$. Hänellä on kolmesataakuusikymmentäviisi erilaista liiviä” (Odojevtseva 1988, 96).

Kirjailija oli maineestaan tietoinen ja pyrki vahvistamaan sitä. Päiväkirjamerkinnöissään vuodelta 1905 Kuzmin kirjoitti, että hänellä on "kolmet kovin erilaiset ja toisilleen niin vihamieliset kasvot". Ensimmäiset niistä "muistuttavat pitkän parran kanssa jokseenkin da Vinciä, hemmoteltua ja näennäisen kilttiä, niissä on jonkinlaista epäilyttävää pyhyyttä, ikään kuin yksinkertaista, mutta monimutkaista". Toisilla on "ranskalaisen kirjeenvaihtajan terävä parta, ne ovat jokseenkin keikarimaiset, tylyllä tavalla kapeat, välinpitämättömät ja pitkästyneet Eulogiuksen kasvot". Kolmannet "viisikymppisen vanhuksen ja nuorukaisen, Casanovan, puoliksi šarlataanin, puoliksi apotin kuivat ja epäluotettavat kasvot, joilla on lapsellisen verevä ja lipevä suu, ovat kaikkein pelottavimmat ilman partaa ja viiksiä, ne eivät näytä vanhalta eivätkä nuorelta”. (Kuzmin 2000a, 61.) Hätkähdyttävän räikeä ja korostetun eklektinen ulkoasu oli jo uran alusta lähtien tärkeä osa Kuzminin hahmoa. Kesään 1906 asti hän sonnustautui polvipituiseen kaftaaniin ja muihin venäläisiin talonpoikaisvaatteisiin, mutta käytti samaan aikaan silmämeikkiä ja sormuksia. Vähitellen hänestä tuli yksi Pietarin kuuluisimmista esteetikoista, joka kontrastisesti yhdisti tarkoituksellisen huolitellun asukokonaisuutensa uskonnollisiin, miltei munkeille ominaisiin arjen käyttäytymismalleihin.

Päiväkirjassaan vuodelta 1934 Kuzmin selitti, että hahmo oli sommiteltu harkiten. Sen jokaisen osan piti vaikuttaa yleisöön - yllättää ja häkellyttää: "Siihen liittyi paljon naamioitumista ja estetismiä. [...] Minun ulkonäköni. Pieni mutta huomattava parta, pottatukka, punaiset saappaat hopeisilla kannuksilla, brokadikankaasta ommellut paidat, kaftaanit ohutta verkaa yhdistettynä hajuvesiin (tuoksuin kuin Kristuksen hautakuva), poskipunaan, silmämeikkiin, jalokivisormusten runsauteen, Aleksandrian lauluihini, ${ }^{3}$ musiikkiini ja makutottumuksiini tämän kaiken oli määrä luoda päihdyttävä vaikutelma" (Kuzmin 2011, 72). Muotitietoisen keikarin statusta lujittivat myös Kuzminin runot, joissa hienostuneita luonnoksia Pietarin boheemien arjesta seurasi ehdottomasti yksityiskohtainen aineellisen maailman kuvaus, esimerkiksi runosikermässä Tämän kesän rakkaus (1906): "Mistä löytäisin sanat, miten kuvata huviretkeä, / Chablis jäissä, paahdettu sämpylä, / Kypsien kirsikoiden imelä akaatti?" (Kuzmin 2000c, 59). ${ }^{4}$

Yksi kirjailijan hahmoon kytkeytyvistä tehokeinoista oli erityinen tuoksu, joka ympäröi Kuzminia. "Sekoitus hajuveden, tupakan ja kärähtäneen sydänlangan tuoksua", kuvaili nuoremman polven runoilija ja kriitikko Georgi Ivanov tunnelmaa, joka vallitsi Kuzminin asuinhuoneessa ${ }^{5}$ (Ivanov 1928, 124). Huoneen asukasta hän luonnehti näin: "Viimein Kuzmin astuu sisään. Paperossi hampaissaan, hajuveden tuoksu, dandyn puku, hajamielisen kevytkenkäinen ilmestys" (Ibid., 126). Ulkoasun ja käyttäytymismaneerien lisäksi näissä kuvauksissa korostuu erityinen tuoksu, joka edeltää Kuzminin saapumista. Ivanov mieltää hajuveden keinotekoisen, sadunomaisen tuoksun olennaiseksi osaksi Kuzminin niin ikään "tyyliteltyä" ja raffinoitunutta habitusta. Muistelmissaan hän tähdensi, että "Kuzminin elämäkerrassa seikat, kuten ajeltu parta, puvun kuosi ja hajuvesilaatu tai missä hän söi aamiaista, 
ovat ensisijaisen tärkeitä” (Ibid.). Vaikka joku saattaa kyseenalaistaa Ivanovin luotettavuuden ja monet muistelmateoksessa Pietarin talvet esitetyistä faktoista kaipaavatkin tarkistusta, kyseistä yksityiskohtaa hän tuntuu heijastelleen totuudenmukaisesti: Kuzmin oli tunnettu keikari ja parfyymien ystävä.

Hajuvedet ylellisyystuotteena ja siten välttämättömänä osana esteetikon elämää mutta samalla myös ehtymättömän henkilökohtaisen kiinnostuksen kohteena saivat merkittävän paikan Kuzminin elämässä ja tuotannossa. 1900-luvun alkuun, eli Kuzminin "estetismin" huippukauteen (jolloin hän oli tekemisissä K. M. Somovin, A. N. Benois'n ja muiden Mir iskusstvan ${ }^{6}$ taiteilijoiden kanssa) sijoittuvassa päiväkirjassa on viljalti viittauksia kukkien ja hajuvesien ostamiseen. Tyypillinen esimerkki tuolta ajalta lienee päiväkirjamerkintä 23 . tammikuuta 1907: "...joimme erinomaista Johannisbergeriä, madeiraa, kahvia ja söimme roquefortia. Poljakov väsähti varsin nopeasti. Puhuimme viinistä, kukista, hajuvesistä, okkultismista, minusta" (Kuzmin 2000a, 312). Kuzmin viittaa hajuvesiin myös useissa runoissaan, esimerkiksi sikermässä Raketit vuodelta 1907: "Kätteni sormet tuoksuvat parfyymiltä / Sulkevat sieluni suloiseen vankeuteen" (Kuzmin 2000c, 82). Toinen huomionarvoinen esimerkki on vuoden 1919 sikermästä Vankeus, runosta Nautiskeleva enkeli, joka heijastelee Kuzminin pettymystä vallankumoukseen (johon hän oli aluksi suhtautunut miltei hurmioituneesti). Siinä hajuvesi symboloi uutta, parempaa elämää, joka odottaa kaikkien sotien aiheuttamien rajoitusten jälkeen: "Jälleen saa korkata pullon Reinin viiniä / Ja hajuvettä ostaa alle kolmensadan ruplan" (Kuzmin 2000c, 641).

Kuzminin luoma hahmo oli yksityiskohdissaan niin vakuuttava, että vielä monien vuosien jälkeen ihailijat haikailivat erilaisten artefaktien perään, joita hän käytti lyriikassaan. Niiden

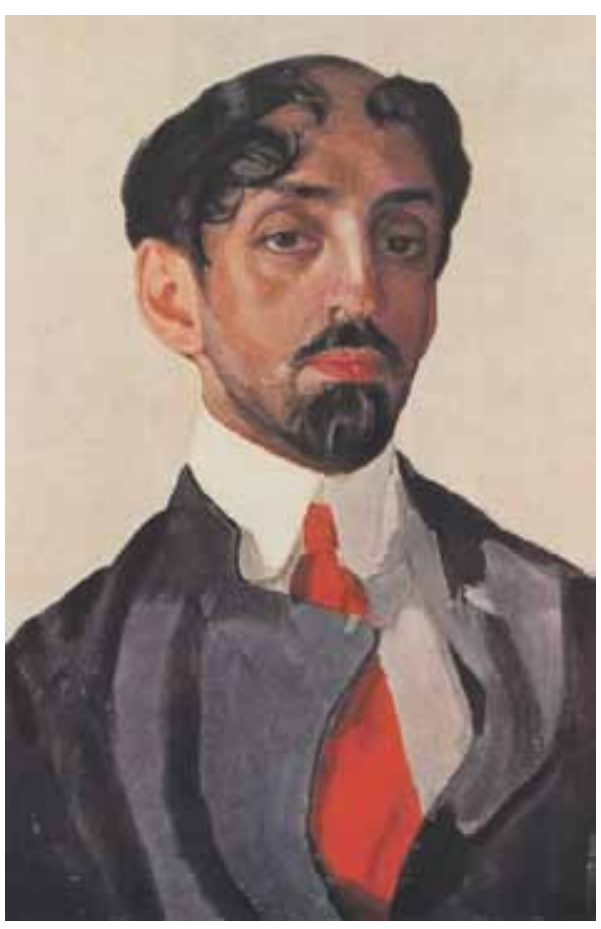

Mihail Kuzminin muotokuva (K. A. Somov, 1909). Lähde: Wikimedia Commons. miellettiin olevan hopeakauden dekadentille esteetikolle kuuluvaa välttämätöntä tarpeistoa. Parfyymeillä oli näiden tuotteiden joukossa oma erityinen paikkansa. Irina Takke, eräs kirjailijan kuuliaisista palvojista kirjoitti hänelle vuonna 1924: "Runonne ovat minulle niin rakkaita ja tarpeellisia, etten voi kuvitella 'mitä olisi', jos Teitä ei olisi maailmassa, samoin kuin en saata kuvitella, että elämästäni pyyhittäisiin pois Puškin, parfyymit tai syksyn lehdet" (Takke 1924).

Kuzminin tapauksessa aromeja, parfyymeja ja tuoksuja voidaan hyvällä syyllä pitää yhtenä mahdollisista koodeista, jonka avulla lähestyä hänen tuotantonsa ja kirjallisen maineensa analyysiä. Tähän oikeuttavat niin olfaktorisen, hajuaistimuksia esittävän kuvaston esiintymistiheys Kuzminin teoksissa kuin tuoksujen erityinen rooli konstruoitaessa kirjailijan julkisuuskuvaa. Hänen teoksensa syntyivät aikakautena, jolloin suosittiin hienostunutta elämäntapaa, joka vaati kukkia ja parfyymejä. Siksi ei olekaan yllättävää, että kirjailijan henkilökohtaiset 
mieltymykset muodin vahvistamina johtivat huomattavan olfaktorisen estetiikan muodostumiseen. Ei liene liioiteltua väittää, että kaikista venäläisistä kirjailijoista Kuzmin "käytti" eniten hajuvesiä, että hän oli "hyväntuoksuisin" venäläinen kirjailija.

Kyseinen piirre on herättänyt tutkijoiden huomion aiemminkin. Antropologi Marija Pirogovskajan mukaan jokainen Kuzminin hahmoon kuuluva elementti "rikkoi porvarillisen säädyllisyyden normeja ja vaikutti käyttäytymisen teatralisoitumiseen" (Pirogovskaja 2018, 324). Tutkijan mukaan erityisesti huomiota herätti kirjailijan "olfaktorinen antikäyttäytyminen": Kuzmin käytti voimakkaita ja makeita naisten parfyymeja muistuttavia tuoksuja, jotka rikkoivat sukupuolinormeja ja lisäksi assosioituivat rienaavasti ortodoksisissa kirkonmenoissa käytettyihin suitsukkeisiin (Ibid.). Gražina Bobilevitš pitää Kuzminin demonstratiivista olfaktorista käyttäytymistä sekä "dandyn olfaktorisena esityksenä" $(2008,9)$ että hänen moniulotteisen hahmonsa heijastuksena: "Tuoksu ilmentää kirjoittajan halua muuntautua 'toiseksi', vaihtaa naamioita ja leikkiä” (Ibid., 2). Todettakoon, että molemmat tutkijat kuvaavat Kuzminin olfaktorista käyttäytymistä hänen aikakautensa kontekstissa kiinnittäen huomiota erityisesti siihen, kuinka dekadentti dandy pöyhkeilee ja halveksii sosiaalisia normeja ja yleistä makua. Kiistämättä laajemman kulttuurisen kontekstin merkitystä tässä artikkelissa olfaktorisia topoksia eli tuoksujen kuvastoa pyritään kartoittamaan Kuzminin tuotannon omista lähtökohdista.

\section{Tuoksu runon teeman osatekijänä}

Kuzminiin erottamattomasti liitetty kukka, josta tuli hänen tunnusmerkkinsä, oli ruusu. Tähän oli useita syitä. Ensinnäkin yksi suosituimmista Kuzminin sanoittamista ja säveltämistä romansseista oli nimeltään Lapsonen ja ruusu ja alkoi näin:

\footnotetext{
Älä hamuile ruusuja keväällä, lapsonen,

Ruusun kesälläkin saathan taittaa.

Varhain keväällä poimitaan orvokit,

Muista, ettei kesällä orvokkeja enää ole.
}

Romanssia esitettiin usein kulttimaineeseen nousseen Kulkukoiran kellarin (1911-1915) suojissa. Taiteilijakabareen rinnalla siitä tuli yksi Pietarin boheemien piirien huolettoman elämän kirkkaimmista tunnuksista maailmanlaajuisten kumouksellisten muutosten aattona. Ei olekaan ihme, että useat tulevat emigranttikirjailijat - muiden muassa runoilijat Irina Odojevtseva (1988, 290-291) ja Georgi Ivanov (1928, 132-133) sekä taidemaalari Mstislav Dobužinski $(1987,279)$ - kirjoittivat romanssista muistelmissaan, mikä oli omiaan vahvistamaan paitsi Kuzminin erityistä statusta kulttuurisessa muistissa myös hänen hahmonsa yhteyttään ruusuihin.

Kaiken lisäksi runoilija käytti ruusuja lyriikassaan toistuvasti rakkauden metaforana. Hänen teoksissaan ruusu tuli saattelemaan ja symboloimaan niin ruumiillista kuin platonista rakkautta: "Epätodellisen kiihkeitä asentoja... / Häpeämättömiä, häveliäitä / Suudelmien kaikki laskuvedet / Valkoisten ruusujen makea tuoksu" (sikermästä Tämän kesän rakkaus, 1906. Kuzmin 2000c, 59-60); "Vuoda, sydän, vuoda! / Puhkea kukkaan, ruusu, puhkea! / Sydän ruusun huumaamana hakkaa. / Rakkaudesta palan, rakkaudesta..." (sikermästä Virrat, 1908. Kuzmin 2000c, 105). Aikalaiskritiikissä Kuzminia alettiin hyvin pian pitää lähinnä rakkauden ja ruusujen laulajana, kuten esimerkiksi akmeisti Nikolai Gumiljovin arvostelussa runoko- 
koelmasta Syksyiset järvet (1912): "Kuzmin etsii rakkautta, ainoastaan rakkautta. Tuntuu, että siihen sanaan mahtuu hänelle koko maailma. Se on - Amor nuolineen ja koteloineen, valoisa enkeli, hyväntuoksuinen ruusupuska" (Gumiljov 1990, 158). Vähitellen muodostunut käsitys osoittautui niin sitkeäksi, että se kantautui aina 1920-luvulle asti. Kuzminin kirjallisen toiminnan 15-vuotisjuhlalle omistetussa runossa Aleksandr Belenson kuvasi runoilijan ruusu kädessään (Kuzmin 2007, 35):

\author{
Vinoilee siluetti Kuzminin \\ Laulaja verkkojen, kyyhkyjen hauraiden \\ Viisauden ohjaama edelläkävijä8 \\ Kantaa ruusua, jonka joku \\ Rakastunut käsin hellin \\ Ojensi, ei runnellut.
}

Ruusu-motiiveille sälöttyi Kuzminin tuotannossa myös muita merkityksiä. Hänen runoissaan esiintyy muun muassa "taivaallisia ruusuja" ja "paratiisin ruusuja", kuten esimerkiksi miltei pilkallisessa kuvauksessa vuodelta 1909, jossa arkkienkeli Gabriel ilmestyy Neitsyt Marialle ilmoittamaan Kristuksen tulevasta syntymästä: "Aamu välkehtii uutta valoa / Taivaallisina ruusut koruttomain kukkapenkkien / Vaan sydän sykähtelee suloisesti / Ja vaate vyötäröä kiristää” (Kuzmin 2000c, 225). Edelleen ruusun tuoksu assosioitui ortodoksisessa jumalanpalveluksessa käytettävään ruusuöljyyn, josta tuli osa runoilijan ulkoista hahmoa ("tuoksuin kuin Kristuksen hautakuva"). Muistellessaan ensimmäistä tapaamistaan Kuzminin kanssa 1900-luvun alussa myös kirjailija Aleksei Remizov tähdensi, että runoilijan ympärillä leijui "kirkollinen" ruusun tuoksu: "Kuzminilla oli tuolloin mustaakin mustempi parta, vyötäröltä kapea polviin ulottuva kirsikanpunainen samettitakki [...] ja katseli niin kuin olisi itse faarao Tut-ankh-a-mon tai saapunut vastikään vanhauskoisten nuotiolta Volgan mutkasta ja tuoksahti voimakkaasti ruusuilta - hänestä huokui kuin ikoneista juhlapyhinä” (Remizov 2002, 7, 114). Kaikesta päätellen ruusun tuoksu, johon liittyy yhtä aikaa romanttiseroottisia ja uskonnollisia merkityksiä, vetosi "kolmikasvoiseen" Kuzminiin ja nivoutui osaksi hänen monitasoista, hämmennystä herättävää hahmoaan.

Runoilijan lempituoksu 1910-luvun alussa oli Coty-brändin parfyymi La Rose Jacqueminot. Tästä seikasta kirjoitti 28. joulukuuta 1913 päivätyssä runossaan Fjodor Sologub (2000, 389):
Loimuaa Jacqueminot'n ruusun tuoksu
Jota Mihail Kuzmin rakastaa
Hiilet hehkuvat takassani kutsuvasti
Tuoksuu taivaalliselta Jacqueminot'n ruusu
Viihtyisissä nurkissa on hiljaista ja hämärää
Koristeellisen maton ruusuille on läikähtänyt karmiinia
Kuinka raukea on tuoksu Jacqueminot'n ruusun
Jota Mihail Kuzmin rakastaa!

La Rose Jacqueminot -hajuvesi on omistettu samannimiselle ruusulajikkeelle "General Jacqueminot". Se on täyteläinen ja kukkaisa tuoksu, jossa on ruusun, jasmiinin ja ambran vivahteita. Aromi on makea ja öljyinen, eikä olekaan ihme, että täyteläisiin, lämpimiin ja 


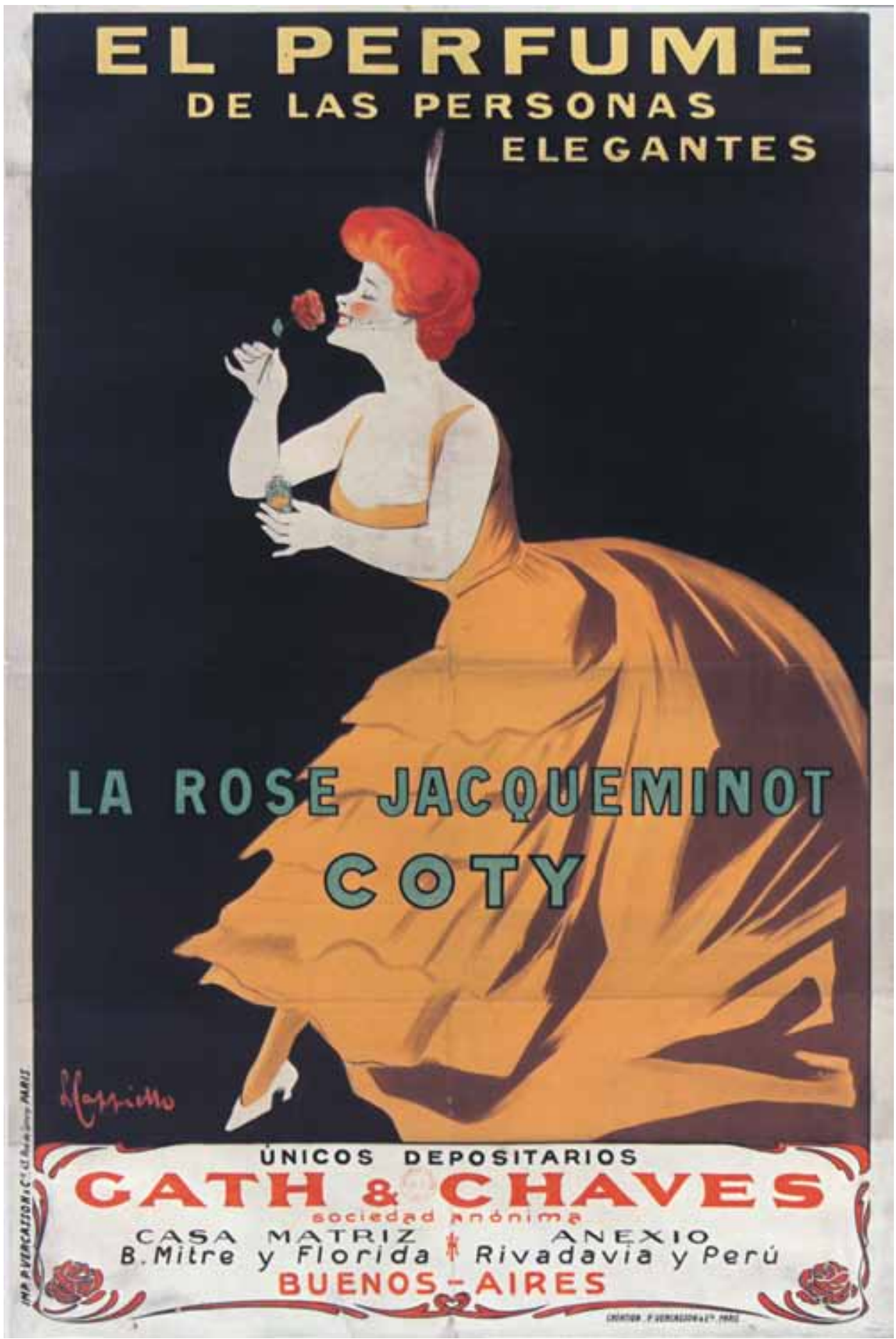

Kuva 2. François Cotyn La Rose Jacqueminot -hajuveden mainos (L. Cappiello, 1904). Lähde: Wikimedia Commons. 
suitsukemaisiin tuoksuihin viehtynyt Kuzmin ihastui siihen. François Cotyn vuonna 1903 luoma hajuvesi lanseerattiin Euroopan markkinoille vuonna 1904 ja kaksi vuotta myöhemmin Amerikan markkinoille. Venäjälle se saattoi kantautua vasta vuonna 1910, kun brändi avasi myymälänsä Moskovassa (Toledano \& Coty 2009, 108). Huolimatta siitä, että tuoksu oli suunnattu naisille, myös kirjailija Aleksandr Kuprinin ja runoilija Nikolai Kljujevin tiedetään suosineen sitä.

Cotyn parfyymistä tuli kiistatta aikakautensa olfaktorinen tuntomerkki. Esimerkiksi Anna Ahmatova mainitsee sen Runoelma ilman sankaria -teoksen pohjalta laatimassaan balettilibreton luonnoksessa:

\begin{abstract}
Kolombinan luona. [...] Vieraita. Kljujev ja Jesenin tanssivat venäläisittäin ripaskaa villisti, kuin ruoskien itseään lahkolaisessa hurmoksessa. Demoni. Tyttö antautuu hänelle kokonaan. Mustia ruusuja. Rakuunan ensimmäinen mustasukkaisuuskohtaus. Hänen epätoivonsa. (Paha juttu - Stravinski aavistaa pahaa). Kellot soivat: "Kiitetty olkoon”. Rose Jaquemineau -hajuvesi. Rampa ja tyylikäs yrittää lohduttaa rakunaa maanitellen häntä jollain perin hämärällä. (Vjatšeslav Ivanovin "Torni”) - Rampa ja tyylikäs on kotonaan... (Ahmatova 2009, 1238).
\end{abstract}

Katkelma punoo yhteen useita eri alluusioita ja ajalle ominaisia realioita, ja on erityisen mielenkiintoista, kuinka kaikki ne kietoutuvat Mihail Kuzminin hahmon ympärille. "Rampa ja tyylikäs" ovat Kuzminia kuvaavia määritteitä, joita Ahmatova Runoelmansa eri versioissa jatkuvasti käyttää: "Frakin alle tuo piilotti häntänsä, / hän on rampa ja tyylikäs... [...] / Irvileuka, kaikkien suosima, / jonka rinnalla löyhkäävin syntinen / on hurskas ja puhdas kuin pulmunen..." (Ahmatova 2008, 218-219). "Rakuunan lohduttaminen" ja nuoren runoilijan itsemurha muodostavat keskeisen juonen Runoelmassa ilman sankaria. Hahmon prototyyppi Vsevolod Knjazev palveli husaarirykmentissä, niinpä Ahmatova nimittääkin häntä teoksen varhaisissa käsikirjoituksissa rakuunakornetiksi (Ahmatova 2009, 260). Vuosien 1910-12 välillä hänen ja Mihail Kuzminin tiedetään olleen aluksi ystäviä ja sittemmin rakastavaisia. Niin ikään fraasi "Kellot soivat: 'Kiitetty olkoon"' palauttaa mieliin aikakauden tunnistettavan realian - hymnin "Kiitetty olkoon Siionin Herra", jonka melodiaa Pietari-Paavalin linnoituksen katedraalin kirkonkellot soittivat. Samalla se viittaa yhteen Kuzminin runoon sikermästä Kukkula kaukana (1912): "Lähden luotasi hiljaa / Sinä jäit parvekkeelle/ 'Kiitetty olkoon Siionin Herra' / Soi toitotus Taurian puistossa" (Kuzmin 2000c, 241). Sikermä, johon runo kuuluu, on omistettu juuri Vsevolod Knjazeville. Jos vielä otetaan huomioon, että seuraavaksi Ahmatovan tekstissä mainitaan Ivanovin "torni”, jossa Kuzmin asui vuosina 1909-1912, palapelin palaset loksahtavat paikoilleen ja muodostavat Kuzminin muotokuvan. Luonnoksissaan Ahmatova toisintaa tyypillisen kohtauksen Pietarin boheemien elämästä ja heidän piirilleen merkittävistä paikoista ja tapahtumista. Tässä kontekstissa Cotyn parfyymistä tulee ikään kuin niiden ruumiillistuma. Tuoksu saattelee viettelyksen ja irstauden teemoja sekä yhdistää ruusun "romanttisen" merkityskentän Kuzminiin, joka runoissaan ylisti ruusuja ja palvoi ruusuisia hajuvesiä. Näin ruusun tuoksusta tuli osa Kuzminin biografista myyttiä, joka jäi elämään muistoissa myös runoilijan kuoleman jälkeen. 


\section{Hajuvesi kirjallisen polemiikin välineenä}

Vuonna 1915 Petrogradissa ilmestyi kaunokirjallinen antologia Jousimies. Kokoelmaa pidetään merkittävänä, sillä sen sivuilla kohtasivat toistensa leppymättömät vastustajat futuristit ja symbolistit. Vladimir Majakovski, Velimir Hlebnikov, David Burljuk, Aleksei Krjutšonyh ja Vasili Kamenski, jotka manifestissaan Korvapuusti yleiselle maulle vuonna 1912 uhkasivat heittää Puškinin ja Dostojevskin yli nykyajan höyrylaivan laidan, julkaisivat nyt yhteisen kirjan aiemmin suureen ääneen halveksimiensa Kuzminin, Aleksandr Blokin ja Fjodor Sologubin kanssa.

Jousimiehessä julkaistuissa runoissaan Mihail Kuzmin kehitteli samoja teemoja, joita oli käsitellyt jo ensimmäisessä runokokoelmassaan Verkot vuonna 1908. Hän kirjoitti rakkaudesta, suven riemuista ja ympäröivästä maailmasta, joka täyttyy eri hajuvesien tuoksuista. Teosten joukossa on kahdesta runosta koostuva vuonna 1914 kirjoitettu sikermä Kesäisiä säkeitä. Ensimmäinen runoista kuvaa helteisenä päivänä vilvoittelevaa lyseolaisten seuruetta ('kaksi daamia ja knalli") ja nuoren rakkauden pienistä vastoinkäymisiä ("kuka ketäkin kutsuu kuumaan vuoteeseen", "tukeva ja murheellinen tenori on väsynyt odottamaan", "hiestä näppyläisenä - ei saa suudella kaulaa"). Toisessa runossa esitetään "riikinkukonsininen silkkitakki" verkkaisella päiväkävelyllä, itsestään soivan pianolan rulla toistamassa "vaimojen lirkuttelevaa villitystä" ja paidat, jotka "kalpenevat laukatessaan" tenniskentällä.

Huomattavaa on, että molemmat tekstit alkavat viittauksella hajuveden tuoksuun. Ensimmäisessä runossa miljöö, luonto tuoksuu hajuvedeltä, eikä toisinpäin: "Varjojen vinot kulmat / Juoksivat saarille päin / Tuoksuu tunkkaiselta hajuvedeltä / Niitetty heinä" (Kuzmin 2000c, 419-420). Toisessa runossa hajuvedeltä tuoksuu kangas ja kuvaannollisuuden, suhteellisuuden määrä kasvaa entisestään: 'Puhkesivat kukkaan ruusut päivänvarjojen, / Niistä tuoksuu 'folle arôme'... / Tällaisena päivänä runoja proosasta / Ei todellakaan saata erottaa” (Ibid., 420). Kuzminin luoma taiteellinen maailma on epätodellinen, vertauskuvallinen ja äärimmäisen esineellinen, artefaktinen. Keinotekoisilla tuoksuilla on Kuzminin runojen maailmassa suurempi rooli kuin luonnollisilla. Rakkauden merkkinä parfyymit tuovat runoihin intiimejä ja häilyvän kepeitä motiiveja. Niin keinotekoiset ruusut, jotka tuoksuvat hajuvedeltä, kuin runot, jotka sekoittuvat proosaan, heijastelevat, kuinka lyyristen hahmojen tunteet heittelehtivät kiihkeästä ihastuksesta hämmennykseen.

Kesäisissä säkeissä käytettyjä kirjoitusajankohdalle ominaisia reaaleja voisi kommentoida näin: ensimmäisessä runossa puhutaan hajusteesta, jonka yhtenä ainesosana on käytetty kumariinia. Sen tuoksu muistuttaa vasta niitettyä heinää. Monissa kasveissa ja kukissa esiintyvää yhdistettä alettiin tuottaa synteettisesti vuonna 1868. Kumariinia sisältävien hajusteiden suosio oli huipussaan 1800-1900-lukujen vaihteessa: vuonna 1882 lanseerattiin legendaarinen Houbigant-merkin hajuvesi Fougere Royale (nimi tulee ranskan sanasta "saniainen"), jonka mukaan sai nimensä kokonainen hajuvesilaatu. Yksi tämän hajustetyypin kuuluisimmista merkeistä on vuonna 1889 ilmestynyt parfyymi Jicky Guerlain. Todennäköisesti vuoteen 1914 mennessä kyseinen aromi oli saavuttanut niin laajojen kansanrivien suosion, että sitä alettiin pitää huonon maun merkkinä. Gražina Bobilevitš on esittänyt, että runon "tunkkainen hajuvesi” viittaisi erityisesti venäläisen A. Siu ja K $\mathrm{K}^{\circ}$-parfyymitehtaan brändiin Svežeje seno (suom. "tuore heinä"), mutta niiden sijaan kyse voi olla melkein mistä tahansa 1910-luvun alussa markkinoilla olleesta suositusta merkistä.

Sen sijaan Folle arôme, johon Kuzmin runossaan viittaa, on Guerlain-merkin vuonna 1912 lanseeraama hajuvesi, jonka nimi kirjoitetaan todellisuudessa Fol Arôme. Sen kehitti par- 
fymööri Jacques Guerlain, jonka käsialaa ovat myös monet muut hajusteet, jotka 1900-luvun ensimmäisellä puoliskolla tunnettiin ympäri maailmaa (L'Heure Bleau, Mitsouko, Shalimar jne). Tuoksultaan Fol Arôme on täyteläinen ja makea parfyymi, jossa on laventelin, ruusun ja vaniljan vivahteita. Kuten edellä kävi jo ilmi, Kuzmin suosi erityisesti tämänkaltaista makeaa ruusun tuoksua.

Kesäiset säkeet antavat aiheen myös pienelle kirjallisuushistorialliselle sivuhuomautukselle, joka liittyy kahden taiteellisen koulukunnan edustajien polemiikkiin. Manifestissaan Korvapuusti yleiselle maulle futuristit hyökkäsivät julkeasti yhtä aikansa kuuluisinta runoilijaa, symbolisti Konstantin Balmontia vastaan: "Kukapa olisi niin hyväuskoinen, että antaisi tuoreimman Rakkautensa Balmontin hajuvesi-irstaudelle? Siinäkö kuvastuu nykypäivän rohkea sielu?” (Burljuk ym. 2014, 22). Vuosi Korvapuustin ilmestymisen jälkeen Majakovski jatkaa Balmontin höykytystä nimittelemällä tätä useampaan otteeseen "parfyymifabriikiksi" (Katanjan 1985, 65) tai, kuten eräässä julkisessa esityksessään, laajentamalla "hajuveden tuoksun" tarkoittamaan kokonaista taiteellista suuntausta: "Vain sellainen runous on demokraattista, joka romuttaa latteiden naamojen ja sielujen vanhan psykologian. Me pirstoimme teidän iänikuisen hajuvedentuoksuisen rakkautenne!" (Ibid., 74). Majakovskin kaltaiselle ankaralle futuristille parfyymit olivat merkkejä pikkuporvarillisesta maailmasta, jossa hienostelevat nuoret herrat ja neidit olivat opetelleet "rakastamaan" lukemalla Balmontin koukeroisia runoja. Ne olivat merkkejä maailmasta, jota vastaan hän taisteli kiivaasti 1910-luvun runoissaan.

Tätä taustaa vasten Kuzminin kontribuutio Jousimiehessä näyttäytyy jopa poleemisena. Kuzmin itse suhtautui futuristeihin oikeastaan varsin positiivisesti. Hän toivoi uuden sukupolven päivittävän venäläisen kirjallisuuden, kuten totesi artikkelissaan vuonna 1914: "Uusia voimia voidaan odottaa vain futuristien suunnalta" (Kuzmin 2000b, 390). Huolimatta futuristeille osoittamastaan sympatiasta, hän antautui yhteisjulkaisussa ironisoimaan sekä heitä että itseään. Rakkaus Kesäisissä säkeissä on korostetusti hajuvedentuoksuista. Näin runoilija puolustaa taiteellista vapauttaan, oikeutta kuvata "kepeitä" tunnekuohuja. Tällaisten runojen julkaisemisen Jousimiehessä voi nähdä olevan samanlainen mielenosoituksellinen teko kuin futuristien manifestit - tällä kertaa vanhemman elämää koristavan, mielihyvän ja nautinnon lähteenä toimivan modernistisen estetiikan ja vapaan luomistyön puolesta.

\section{Hajuvesi taiteellisen maailman elementtinä}

Parfyymien näkökulmasta kiinnostava on myös Kuzminin kirjoittaman draaman Neron kuolema ensimmäisen näytöksen neljäs kohtaus (Kuzmin 1994, III, 329):

\footnotetext{
(Metelöivä joukko nuorukaisia ja neitoja laskeutuu alas portaita. Yksi nuorukaisista on ilmeisesti lähdössä, hänen yllään on matkaviitta, palveluspoika kantaa matkalaukkua. Kaikki nauravat ja suutelevat lähtijää.)

Nuorukainen. Lizzie mikä sen hajuveden nimi on? Unohdan kaiken.

Lizzie. Emeraude, emeraude! Kirjoittaisitpa sen ylös.

Nuorukainen. Tahdotko tuoksua smaragdilta?

Lizzie. Mikä ääliö!
}

Kirjoittaja on tässä kohtaa hieman epätarkka: kyseinen hotellikohtaus liittyy vuoteen 1919, kun taas hajuvesi, jonka rakastunut nuori mies haluaisi hankkia Lizzielleen, ilmestyi kaksi vuotta myöhemmin. Emeraude Coty lanseerattiin vuonna 1921 ja sitä tuotettiin (muunnellen 
reseptiä hieman) koko 1900-luvun ajan. Kuzmin sai idean näytelmäänsä vuonna 1924 ja kirjoitti sitä vuosien 1927 ja 1929 välillä. Neron kuolemaa ei monien muiden myöhäisten teosten lailla esitetty eikä julkaistu kirjailijan eläessä. Sen ensimmäinen painos on vasta vuodelta 1977. On vaikeaa sanoa, milloin yllä mainittu katkelma on kirjoitettu, mutta ei ole epäilystäkään, etteikö Emeraude-hajuvettä olisi tunnettu Neuvosto-Venäjällä jo 1920-luvun keskivaiheilla. On ilmeistä, että vielä vanhempanakin miehenä Kuzmin oli intohimoinen

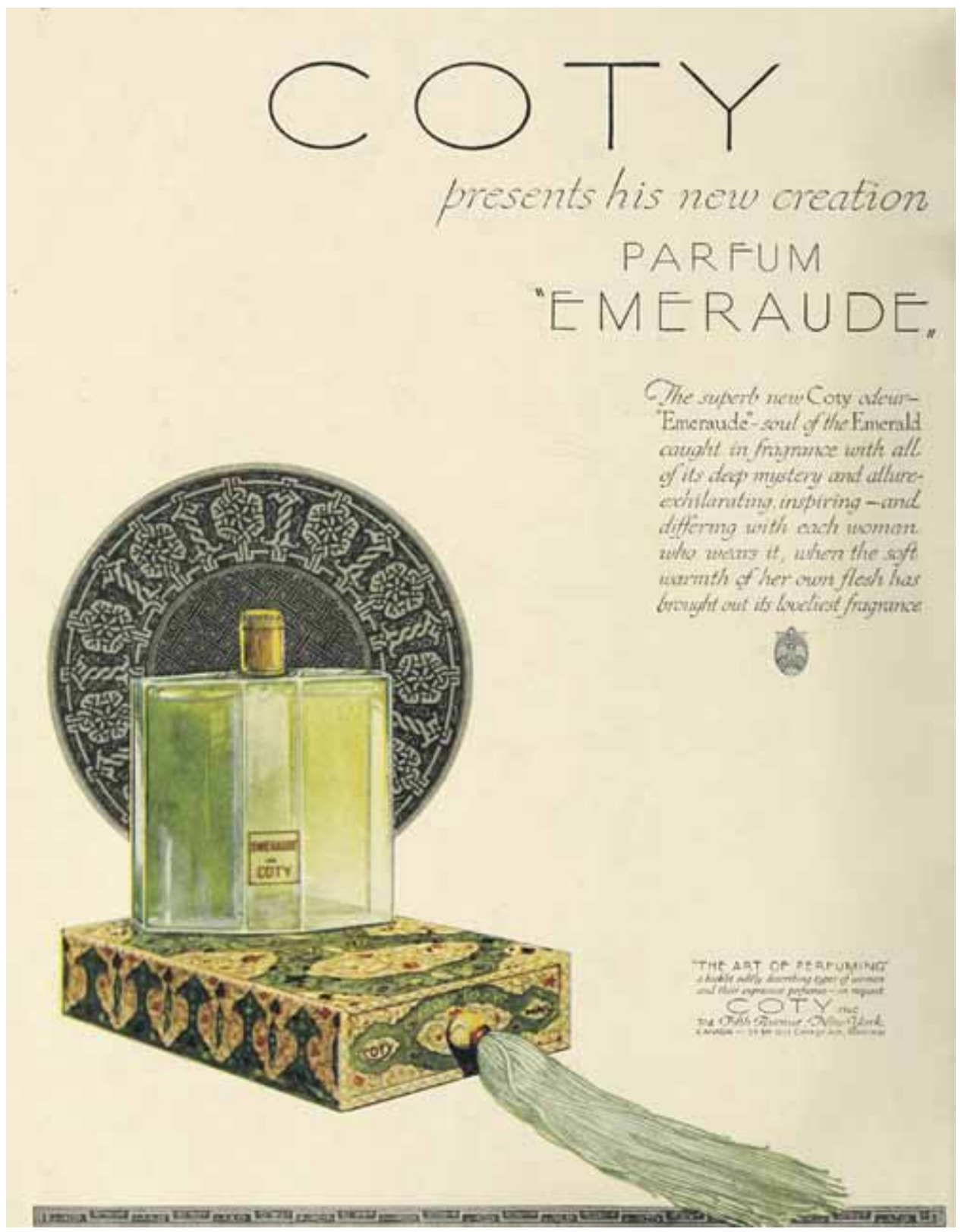

Kuva 3. Emeraude Coty -tuoksun mainos vuodelta 1923. Lähde: Wikimedia Commons. 
parfyymien harrastaja ja seurasi kiinnostuneena, millaisia uutuuksia hajuvesimarkkinoille ponnahteli.

Miltä Lizzie sitten olisi tuoksunut, jos olisi saanut ihailijaltaan hajuvesipullon? Emeraude Cotyn tarina on varsin mielenkiintoinen - aikanaan suosittu tuoksu jäi historiaan Shalimar Guerlain -nimisen parfyymin edeltäjänä. Emeraude ilmestyi jo neljä vuotta ennen Shalimaria (joka lanseerattiin 1925), mutta tunnetuimman itämaisen tuoksun mainetta niittää jälkimmäinen. Ilmeisesti Emeraudesta puuttui Guerlainin vallankumouksellinen tulokulma. Shalimar nimittäin miellettiin uudenlaiseksi, "epäparfyymimäiseksi parfyymiksi": siinä oli syvempi tuoksu ja nahkan, tervan, savun ja vaniljan vivahteita. Emeraude sen sijaan oli tavallisempi, "pelkästään hajuvesi": kaunis itämainen kukkaistuoksu, joka haihtuessaan avautui puumaisena. Näin ollen Lizzie ei olisi tuoksunut smaragdilta, vaan klassisemmin - hänen hajuvedessään olisi ollut lämmin ja makeahko pihkaisen itämainen aromi, joka olisi vivahtanut ambraan.

Entä mistä syystä Kuzmin viittaa Neron kuolemassa juuri Emeraudeen? Yhtäältä tämä on kirjailijan omaan hahmoon liittyvä koskettava yksityiskohta: eläessään 1920-luvulla köyhyydessä ja puutteessa kirjailija edelleen seurasi mielenkiinnolla hajuvesiuutuuksia, joita hänen tuskin oli mahdollista itse hankkia. Toisaalta ihastunut nuorukainen, joka haaveilee lahjoittavansa Lizzielle hajuvettä nimeltä "Smaragdi”, leikittelee suositulla ilmaisulla "Olet aarteeni", kuten rakastavaiset tapaavat toisilleen sanoa. Jalostumisen motiivi - kun jokin, mikä ei aiemmin sitä ollut, muuttuu aarteeksi - on läsnä läpi koko näytelmän, esimerkiksi kuvattaessa Neroa, tuhlailevaista, typerää hallitsijaa, joka sisustaa palatsiaan kohtuuttomilla summilla ja käskee lannoittaa peltoja norsunluujauheella tavallisten ihmisten kärsiessä niukkuudesta ja nälästä. Kuzminin draaman keskeinen ajatus olikin rinnastaa Neron aika 1900-luvun alkuun: tuhlaileva elämäntapa ja kykenemättömyys erottaa kallisarvoinen arkipäiväisestä lienee ollut ominaista molemmille aikakausille.

Joka tapauksessa Kuzmin sijoittaa draaman tapahtumat tiettyyn aikakauteen. Kuvatessaan tunnelmaa kirjailija hyödyntää muutamia tarkoinvalittuja reaaleja - erityisesti olfaktorisen, eli hajuaistimusten tason yksityiskohtia, ja mielikuvia, joita tuoksuihin liitetään. Tätä tehokeinoa Kuzmin käytti läpi koko uransa - suorat viittaukset olemassa oleviin hajuvesilaatuihin palauttavat muistiin "ajan hengen".

\section{Tuoksu kulttuurisessa muistissa}

Edellä analysoitiin kolmea pientä tapausta Mihail Kuzminin teoksissa. Viittaukset eri tuoksuihin kätkevät taakseen konkreettisia kulttuuriseen taustaan liittyviä juonia, joita tässä pyrittiin rekonstruoimaan parfyymeihin liittyvien tietojen avulla. Olfaktoriset, hajuaistimuksiin liittyvät koodit ovat tavallisesti hyvin vaikeita rekonstruoida, sillä niin kaunokirjallisista teoksista kuin erityyppisistä omaelämäkerrallisista teksteistä mainintoja tuoksuista löytyy hyvin harvoin. Mihail Kuzminin tapausta voi pitää ainutkertaisena, sillä hän käytti hajuvesiä luodessaan omaa kirjallista hahmoaan ja biografista myyttiään. Niinpä tuoksut jäivät hänen kohdallaan elämään kulttuurisessa muistissa.

Pyrkimyksenä jatkaa ja kehittää Bobilevitšin (2008) ja Pirogovskajan (2018) huomioita voidaan tulla johtopäätökseen, että Kuzminin tuotannon olfaktorisen koodin analyysissä on välttämätöntä huomioida aikakauden kulttuuristen suuntausten lisäksi hänen yksilölliset taiteelliset käytäntönsä. Voidaankin tehdä eräänlainen yleistys: taiteellisen uransa aikana Kuzmin hylkäsi monet varhaisista teoksistaan, aiemmin käyttämänsä runokuvat ja myytit, 
mutta pysyi uskollisena kukkien ja hajuvesien palvojana. Ihastus niihin säilyi runoilijan kuolemaan saakka merkkinä hänen rakkaudestaan kaikkeen inhimilliseen ja tähän maailmaan.

Venäjästä suomentanut Riku Toivola

\section{Viitteet}

1 Kuzminin tuotannosta on tähän mennessä suomennettu vain otteita: Siivet. Suom. M. Anhava. - Miesten kesken: miesten välinen rakkaus maailmankirjallisuuden valossa. Helsinki: Otava, 1993; Mihail Kuzminin runoja. Suom. R. Toivola. - Ajan kohina. №3, 2015, 88-91.

2 Englantilainen George Bryan Brummell (1778-1840), paremmin tunnettu nimellä "Beau Brummell", oli kenties historian ensimmäinen dandy.

3 Vuonna 1906 symbolistien Vesy-aikakauslehdessä julkaistu runosikermä.

4 Suomennoksissa ei välity Kuzminin tapa käyttää laajaa runomittojen ja erilaisten riimien sekä antiikista periytyneiden runomuotojen repertuaaria. Aikalaistensa tavoin Kuzmin käsitteli säkeitään kokeellisesti; hänen teoksissaan myös verse libre, vapaamittainen runo, alkoi juurtua venäläiseen kirjallisuuteen.

5 Kuzmin asui tuolloin runoilija Vjatšeslav Ivanovin kuuluisassa "Tornissa", joka oli yksi symbolistitaiteilijoiden tärkeimmistä kohtauspaikoista.

6 Pietarissa vuosina 1898-1924 toiminut taiteellinen ryhmittymä (suom. 'Taiteen maailma'), jonka periaatteita olivat puhdas taide ja elämän muokkaaminen taiteen avulla.

7 Sergei Poljakov (1874-1943) oli venäläinen taidemesenaatti ja kirjankustantaja.

8 Runoilija leikittelee Kuzminin runoteosten nimillä.

\section{Lähteet}

Ahmatova, Anna (2009), Poema bez geroja. Proza o Poeme. Nabroski baletnogo libretto: Materialy k tvortšeskoi istorii. Red. N. I. Kraineva, O. D. Filatova. Sankt-Peterburg: Izdatelski dom "Mir". Ahmatova, Anna (2008), Valitut runot. Suom. M.-L. Mikkola. Helsinki: Tammi.

Bobilevitš, Gražina (2008), Michail Kuzmin's Olfactory Aesthetics. - Russian Literature, LXIV, 1, 1-17. https://doi.org/10.1016/j.ruslit.2008.07.001

Burljuk, David \& Krutšonyh, Aleksandr \& Majakovski, Vladimir \& Hlebnikov, Viktor (2014), Korvapuusti yleiselle maulle. Suom. E. Mäntysaari. - Venäläisen avantgarden manifestit. Toim. T. Huttunen. Helsinki: Osuuskunta Poesia.

Dobužinski, Mstislav (1987), Vospominanija. Moskva: Nauka.

Ivanov, Georgi (1928), Peterburgskije zimy. Paris: Rodnik. 
Gumiljov, Nikolai (1990), Pisma o russkoi poezii. Moskva: Sovremennik.

Katanjan, Vasili (1985), Majakovski: Hronika žizni i dejatelnosti. 5-e izd. Moskva: Sovetski pisatel.

Kuzmin, Mihail (1994), Teatr, in 4 vols. Vol. I-III. Ed. A. Timofejev, V. Markov, G. Šeron. Oakland: Berkeley Slavic Specialties.

Kuzmin, Mihail (2000a), Dnevnik 1905-1907. Red. N. A. Bogomolov, S. V. Šumihin. Sankt-Peterburg: Ivan Limbah Press.

Kuzmin, Mihail (2000b), Proza i esseistika, in 3 vols. Vol. 3. Moskva: Agrapf.

Kuzmin, Mihail (2000c), Stihotvorenija. Red. N. A. Bogomolov. Sankt-Peterburg: Gumanitarnoje agentstvo Akademitšeski projekt.

Kuzmin, Mihail (2007), Mihail Kuzmin: Venok poetu. Red. A. Burlešin. Sankt-Peterburg: Vita Nova.

Kuzmin, Mihail (2011), Dnevnik 1934 goda. Red. G. A. Morjev. Sankt-Peterburg: Ivan Limbah Press.

Odojevtseva, Irina (1988), Na beregah Nevy. Moskva: Hudožestvennaja literatura.

Pirogovskaja, Marija (2018), Miazmy, simptomy, uliki: zapahi meždu meditsinoi i moralju v russkoi kulture vtoroi poloviny XIX veka. Sankt-Petersburg: Izdatelstvo Jevropeiskogo universiteta v Sankt-Peterburge.

Remizov, Aleksei (2002), Zavituška. - Sobranie sotšinenii v 10 tomah. T. 7. Moskva: Russkaja kniga.

Sologub, Fjodor (2000), Stihotvorenija. Red. M. Dickman. Sankt-Petersburg: Gumanitarnoje agentstvo Akademitšeski projekt.

Takke, Irina (1924), Pismo M. Kuzminu. Tsentralnyi Gosudarstvennyi Arhiv literatury i iskusstv (Sankt-Peterburg). F. 437. Op. 1. № 167. L. 10.

Toledano, R. B. \& Coty, E. Z. (2009), Francois Coty: Fragrance, Power, Money. Pelican Pub Co Inc.

\section{Kuvat}

Kuva 1: https://commons.wikimedia.org/wiki/File:Konstantin_Somov_-_portrait-of-mikhail-kuzmin-1909.jpg (tarkastettu 7.12.2021)

Kuva 2: https://commons.wikimedia.org/wiki/File:La_Rose_Jacqueminot_Coty.jpg (tarkastettu 7.12.2021)

Kuva 3: https://commons.wikimedia.org/wiki/File:Coty-Emeraude.jpg (tarkastettu 7.12.2021) 